\title{
Carved ceramic: gauged brickwork in Valencia city centre
}

\author{
V. Cristini \& J. R. Ruiz-Checa \\ Universitat Politécnica de Valéncia, UPV, Spain
}

\begin{abstract}
The presence of gauged brickwork is a tangible reality in Valencia City Centre (Spain). Since the latest part of the XVII C., gauged bricks are visible in the most detached façades of historical buildings. On the one hand we can recognize structural performances, in arches, columns and walls; on the other, we have to take constance of decoration solutions in columns, pillars and capitals. Bricks are incredibly carved, in a curious set of solutions. Where can we find this constructive language and techniques? Why can we discover such incredible solutions with carved bricks?

The study, as a part of a wider research, focused on traditional brickworks from Valencia, tries to analyze and describe historical, technical and constructive doubts or answers about such detached "ceramic folds", visible both in the religious, and in the civil architecture of Valencia City. Above all we can discover these technical solutions in casings, door frames, eaves and capitals decoration, as the study would explain and describe.

Keywords: gauged brickwork, ceramic decoration, traditional masonry, brick finishing solutions. Section: Heritage masonry building.
\end{abstract}

\section{Introduction: brick employment in Valencia city centre}

If we approach the discipline of edaphology, a branch of soil science, we can define the urban area of Valencia-Spain, as a wide depression of tectonic origin, shaped by different "physiographical units" that stratify the plain flood basin of Turia River, that runs through the city of Valencia. The origin of brick employment can go back to the foundation of the city [1]. We know that in 138 B.C., Roman soldiers founded a city in the shores of the Turia, close to its river mouth into Mare Nostrum. The general Junio Bruto founds an urban core that 
surrounds the alluvial plains, featured by marshy areas, rich in limes, clays and sediments full of iron oxides. After the decline of Roman Empire, the city fell under the control of the Gothic Empire and after, under the Muslim one.

Guadelete battle (711) makes the rapid invasion of the Muslim troops, supervised by Muza and Tarik, possible. The organization of the territory, in the eastern region of the peninsula, was structured into a defined area, called Sharq al Andalus, headed by Balansiya (Valencia) centre, while the capital also becomes known as Madinat al Turab, the city of clay.

Therefore these are the historical bases that we have to consider in order to focus our attention on the use of gauged bricks in Valencia city centre. It is not a question of technical application merely guided by the aesthetic taste and mode, but rather it's a question of slow and progressive evolution of brick employment, that is still possible to analyze in the Valencia city centre.

\section{Gauged brickwork in Valencia city centre}

At the end of the $16^{\text {th }}$ century, the city centre of Valencia witnessed the progressive presence of gauged brickwork, both in the civil and in the monumental urban architecture; this is a fundamental moment in which the city is going through a transition from stone constructive prominence to new ceramic ornamental role. Local lime stones, like Godella stone, or other sedimentary organic types, as Borriol, Ulldecona ...or other marmoreal lime stones, typical of Spanish east coast area, give a free pass to the clay, which is blended in less "orthodox" applications, not only constructive.

Throughout the XIII-XIV centuries the city has lived a great constructive height with monumental works made in stone, perfectly carved, with extraordinary technical virtuosities [2, 3] but the stone prominence is progressively reduced, due to high constructive costs and to the progressive economic decadence of the Mediterranean Basin. For these reasons, in $15^{\text {th }}$ century stone has a minor significance compared to brick. It limits itself in decorations or ornaments, used above all in plinths, doors and window frames, and for this reason it was relegated to a second place.

The emulation of the classical architecture, which begins in the city under the influence of the Italian Renaissance, progressively acquires a decorative language that imitates Roman and Hellenic models. Therefore Renaissance local architects cannot resort to the medieval masteries or to the "Golden Age" resources of Valencia (XIV century), fig. 1. For all these reasons they were forced to use bricks, which were more economic, easy to produce, autochthonous and present in the city from its Roman foundation.

So the architects face themselves to a problem to solve. They try to recover the language and architecture of Ancient Rome but they have to focus on a different material. The solutions that they adopted were quite different. The simplest and most common way was to cover brick façades and brick details with stucco or paint to simulate a uniform, monolithic surface, scored to look like stone. But... step by step, the pleasure in the rediscovery of classical architecture opens the way for a new sensibility, oriented to complex and 

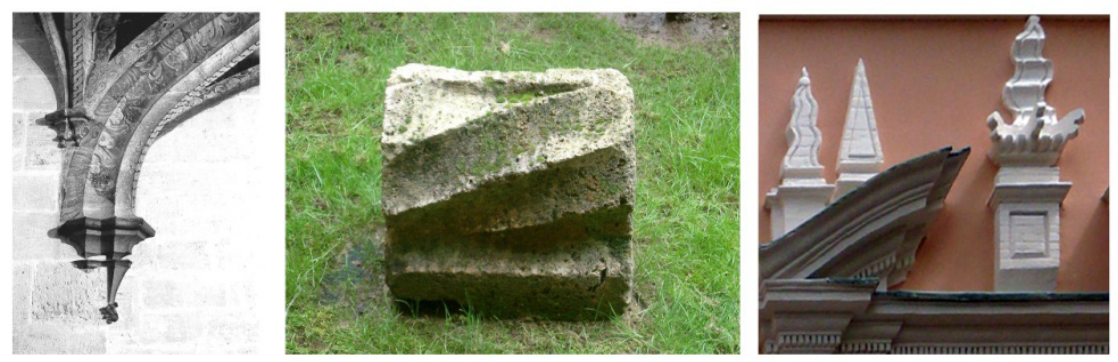

Figure 1: From stone virtuosities to brick technical details. Gothic details from La Trinidad and Santo Domingo Monasteries (Gotichmed [4]) and Marques de Campo façade (Cristini; Ruiz-Checa).

original forms, the peak of which would be seen and felt at the beginning of the $17^{\text {th }}$ century.

The capacity of well-prepared local craftsmen will make possible the match between brickwork and strange and unusual forms. Another solution that we can find for it, is the exuberance of gauged brickwork, paired up with plaster and stucco, materials that facilitate the complex richness of ornamentation. Monumental architecture continues prospering in "two tones", until the ends of 18th century. White stone versus red bricks, this is the trend that is prospering in these ages. The brick and stone combination goes on creating a strong effect in façade layouts, and the brick begins to have an exceptional part in all of it. The moment in which incredible "ceramic folds" have extraordinary quality, takes place especially throughout these centuries, from the shy beginning of Renaissance Architecture (end of the $16^{\text {th }}$ century) up to the eclectic trend of the $19^{\text {th }}$ century.
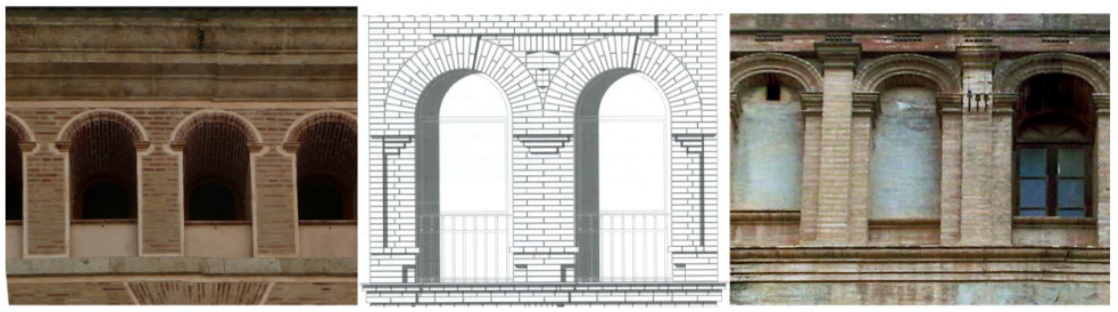

Figure 2: $\quad$ Arcades: San Carlo Borromeo Church, Escuela Pias College and Royal College Seminar Corpus Cristhi, Valencia (Cristini; Ruiz-Checa).

The technical solutions of gauged brick that we can find in Valencia are both structural, as well as decorative. The most constructive employment is detected in special pieces for eaves, corners, or lintels and arches; on the other hand the most decorative use is visible in frames solutions, pilasters, capitals and ornamental tops. The quality of the brick is variable; it's about both of pieces 
that are cut in situ, as well as of elements that are molded with special forms [5]. Also, the constructive quality of raw material changes quite enough. We especially testify the search of uniform clays and rather of the "limy/marly" type, that thanks to the presence of carbonates, that eliminate the grease, allow the control of the retraction of the pieces molded when fired.

\section{Structural employment gauged bricks}

Gauged bricks have been a great technical solution to solve architectural elements like series of arches, lintels and building corners. The high cost of the specialized masons makes of gauged bricks a special resource, for public places such as churches or noble buildings. It is the case of the Valencian Archbishop Juan de Ribera, one of the most influential figures of the time, who promotes an important change in the Valencian religious architecture.

That is why, the set of the great trapezoidal building of Royal College Seminar of Corpus Cristhi (1585-1615), promoted by Juan de Ribera, presents an important point of inflexion in the transition architecture, in which Gothic stereotomy moves away and a mature Renaissance language starts giving the first steps towards the guideline of Serlio, Vignola or other treatise writers.

The series of arches of the main façade can be considered one of the initial examples of employment of gauged brick in the city of Valencia, which opens the way to subsequent applications of the same one in the city. A detached example in this case is Condes de Alpuente Palace (built at the beginning of $18^{\text {th }}$ century) where gauged bricks have a plastic notable force, both in the eaves as well as in the big tympanums and cornices that mark the main façade. The same features are also visible in the principal elevation, in this case more late, of the Marques de Campo Palace (1857) where both in the façade, as well as in the court, we can discover a lot of details with gauged bricks for the series of arches, beads and window brick moulds.

Some private palace, with better constructive quality, presents small details created with special pieces, defined with neat molds; it is the case of corners made of bricks of special curved profile or eaves with stamped elements, fig. 3 . For example, in some cases, we can analyze corners, details and eaves that present rubbed and gauged brick profiles, like Pineda Palace (1728), or in more recent buildings like the University of Valencia (1839) or the set of Ancient Conciliar Seminar (1853).

Generally, the ceramic pieces present curvilinear profiles, both concave, as well as convex, to solve the transition of planes and surfaces. They are pieces that quite common are repeating, along the analyzed surfaces, of regular and rhythmic form, in many cases marked by pumped profiles, fig. 2. It is also common to find trapezoid special elements for lintels, niches and arches, in most of the hand cut and continually measured examples. 

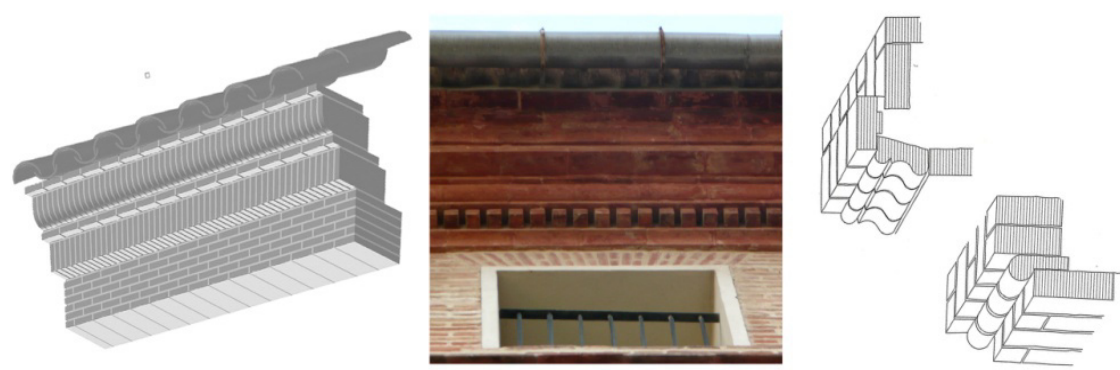

Figure 3: $\quad$ Cornices and dentils: Pineda Palace details and common solutions visible in Valencia City Centre (Cristini; Ruiz-Checa).

\section{Decorative employment of gauged bricks}

The employment of these solutions, is due especially to the search of exact uniformity of the ceramic pieces, placing together with only some scanty $\mathrm{mm}$ between bricks joints. Moreover, in many cases, it is possible to see as the placement of these special pieces, quite joint-less, foresees the use of putty of lime instead of mortar, often colored to give the wall a totally homogeneous appearance $[6,7]$. Therefore, we pass from brick treatment, as unit, to the concept of wall, as a continuum and compact surface, thanks to the polishing and rubbing (esmolado) of ceramic pieces, especially in their exterior faces. If in case of the structural gauged brickwork the care in the disposition of the pieces is more agile...in case of decorative gauged brickwork details, the pieces need to be neatly hand cut, and totally craft defined [8].

The decorative virtuosity of brick, which started in the Roman world, is going through a decisive moment in the history of the architecture [9] in Italy, especially with architects like Peruzzi (Farnesina Palace), Borromini (Filippini and Propaganda Fide sets of buildings), Guarini (Carignano Palace) and Vanvitelli (Naples Royal Palace). All these influences come to Valencia and to the south/east coast of Spain. "Robba minuta" of Borromini, better known as the unitary pieces of architecture, which constitute the body of a building, are the base of the ceramic virtuosity that propagates towards the Iberian peninsula.

The most important is the Royal Basilica-Virgen de los Desamparados (1653) of Valencia, where both dark-red as well as yellowish bricks, are used in cornices, tympanums and capitals. Almost contemporary, it is also the Communion Chapel in St Martin Church (1669-1674), where the columns, which are leaned to the front, and made out of thick bricks, joint-less, are decorated by gauged brickwork, so as to give shape to the Corinthian capitals, in a plastic sequence manner that has nothing to envy when it comes to the main church front in stone, figs. 4-5. 

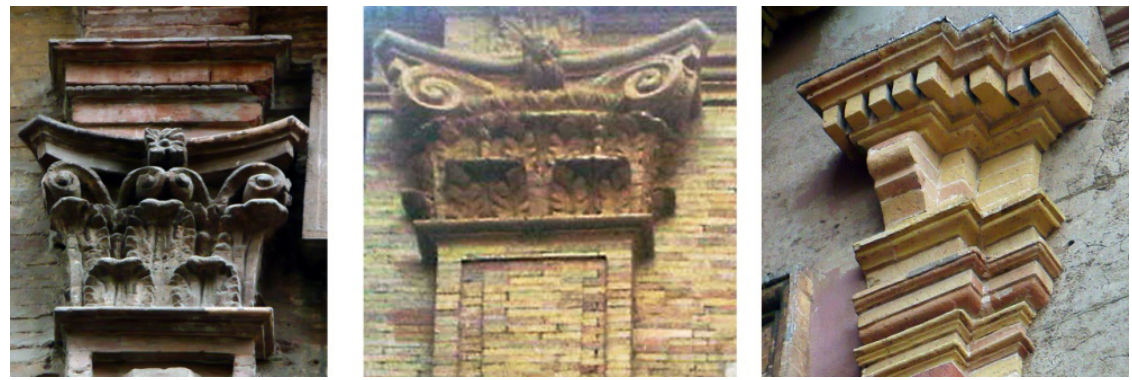

Figure 4: Scrolled volutes and capitals with "marly" bricks: Condes de Alpuentes Palace, Communion Chapel in St Martin Church, Royal Basilica, Valencia (Cristini; Ruiz-Checa).
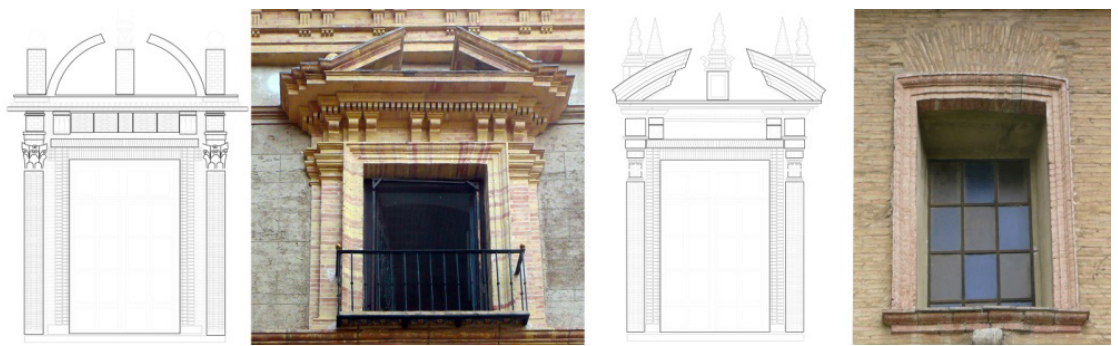

Figure 5: $\quad$ Broken pediments, brick moulds and pilasters: Condes de Alpuente Palace, Royal Basilica, Marques de Campo Palace, St. Ursula Church (Cristini; Ruiz-Checa).

The pieces used in the decoration details, unlike the structural ones, are with templates and, at the same time, in a lot of cases they are always well outlined and shaped by hand. The special decorative elements are not repeated, along the analyzed surfaces, they are quite "unique" components, sometimes also with terracotta details, located in a specific point of the wall, and they are different from the others close to them, fig. 6. They are rubbed and refined in situ, just as it would be done for a sculpture $[10,11]$.
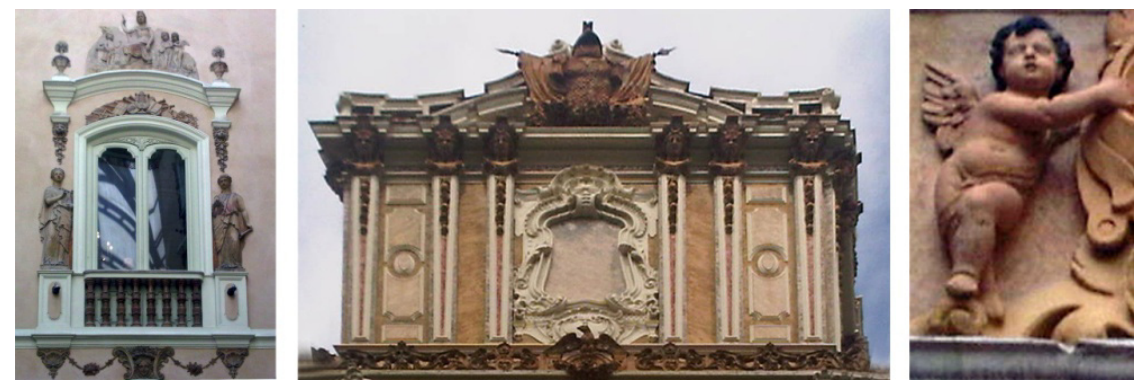

Figure 6: Terracotta details: Marques de dos Aguas Palace and Communion Chapel in St. Martin Church (Cristini; Ruiz-Checa). 
Gauged brickwork is expensive, but cheaper in complex stone decorations; for this reason it is also an important resource for drums, domes and bell towers, fig. 7. The height of these structures makes the employment of bricks possible, in guaranteeing the "orthodox" finishing solutions, but simultaneously more economical that the stony one.
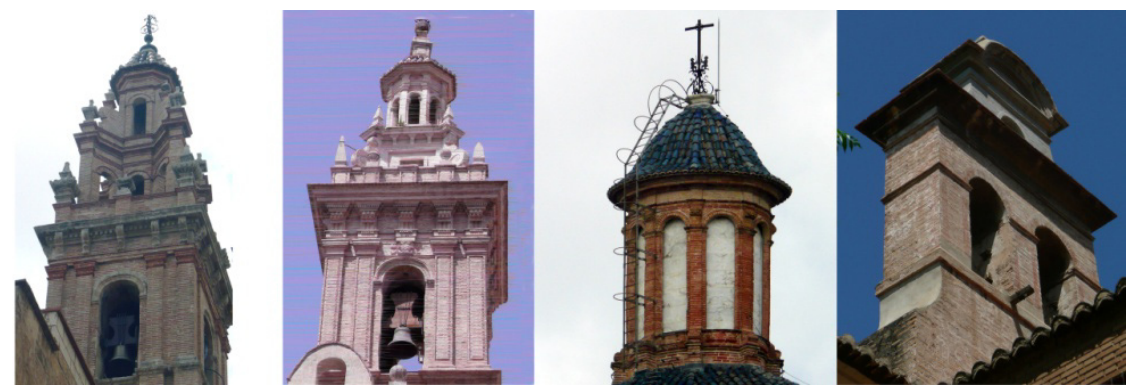

Figure 7: Bell Towers with gauged brickworks: San Esteban Church, Royal College Seminar Corpus Cristhi, Royal Basilica and St. Ursula church examples (Cristini; Ruiz-Checa).

San Bartolomeo tower (1703), and the belfries of San Lorenzo Church (1746), San Valero Church (1676), San Nicolas Parish (1658) are the witnesses of it. Also the drum of the Royal Basilica (1653) of Valencia is a good example of it. In these cases, it's also common to reinforce the finishing appearance of brickworks thanks to red oxide painting layer.

In more recent monumental buildings, it is already possible to see how the double chromatic stone/brick combination takes advantage in moldings and auctions [12].

It is the example regarding the surfaces of the Congregation Church (17251736), the San Miguel and San Sebastian Parish (1726-1739), the number of Escuelas Pias (1739-1773), the Ancient Courthouse (1756-1762) and the Casa Vestuario Building (1800). Thanks to the study of these elevations walls, with a classic structure and layout, it is possible to appreciate, how along the $18^{\text {th }}$ century, the quarry shows a small revival, under the push of the neoclassic taste and of the hierarchic composition of buildings fronts, fig. 8 .
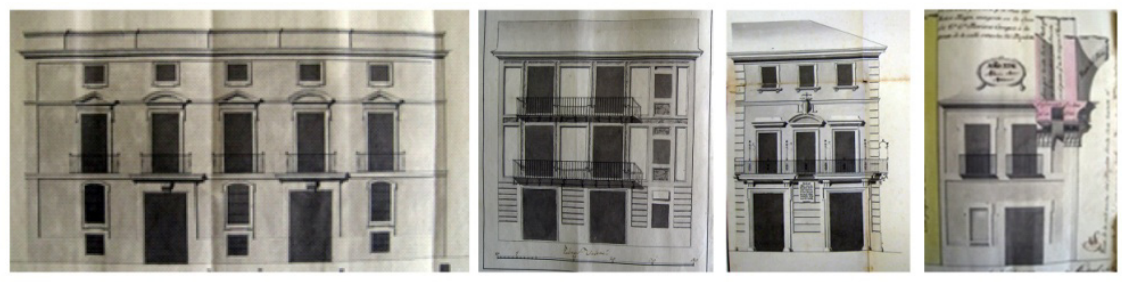

Figure 8: Stone and bricks moulds details visible in some $18^{\text {th }}$ century projects; Calle del Magistre/ Calle Birbe/ Casa Vestuario/ Calle Migalete (pictures from Historic Archive of Valencia). 
But it is a brief pause; the modernism and the eclectic language will again apply the versatility of the ceramic and bricks, especially in the Ensanche area, the nineteenth-century urban extension of the city of Valencia

\section{Conclusions}

The presence of the clay in Valencia City centre, in both constructive features, as well as in decorative aspects, shows deep roots, which begin in the Roman Era, with the foundation of the city. The constructive wisdom of late medieval stonemasonry leaves a real "fingerprint" in stereometric applications. These are perfectly visible in the middle XV-XVI centuries, in both monumental architecture, as well as palatial or civil one. There is a complex, varied and heterogeneous set of constructive and decorative solutions, which change and simultaneously repeat themselves in different urban examples, as it has been shown in this paper. There is a huge lack of constructive studies that include these topics, and that is why this research is considered an interesting starting point for subsequent advances and value of the local brickwork, specially the gauged one.

\section{References}

[1] SIAM, Servicio Arqueologico Municipal (Municipal Archaeological Bureau) www.valencia.es

[2] Calvo López, J., "Estereotomía de la piedra", en AA.VV., Master de restauración del Patrimonio Histórico. Área 3: Intervención y técnicas, COAM Ed., Murcia 2004, pages 115-151

[3] Zaragozá A.; Iborra F, in "Otros góticos: Bóvedas de crucería con nervios de ladrillo aplantillado y de yeso, nervios curvos, claves de bayoneta, plementerías tabicadas, cubiertas planas y cubiertas inclinadas", Historia de la ciudad IV. Memoria urbana, ICARO Ed., Valencia 2005, pages 69-88

[4] www.gothicmed.es

[5] AA.VV., Guía de Arquitectura de Valencia, Icaro Ed., Valencia, 2007

[6] Lynch, G., Gauged Brickwork, a technical handbook, Donhead Ed., Shaftesbury, chapter 6, 2006

[7] Warren J., Conservation of brick, Butterworth-Heinemann Ed., Oxford, 1999

[8] Campell J., Price W., Brick. A world history, Thames \&Hudson Ed., London, 2003

[9] AA.VV., Rilievo e analisi morfologico descrittivo dei paramenti murari, edited by Ministero della ricerca scientifica e tecnologica, Kappa, Roma 2003[10] Carbonara G., Atlante del restauro, Utet Ed., Turin, Vol.1Chapter B.2, 2007

[10] Burn, R.S., Masonry, Bricklaying and Plastering (1871 Ed.), Donhead Ed., Shaftesbury, 2001

[11] Bérchez J., Arquitectura y academicismo en el siglo XVIII valenciano, Alfons el Magnànim Ed., Valencia, 1987 